\title{
Impact Of Training And Development On Employee Loyalty: The Case Study Of Beton 6 Corporation
}

\author{
Nguyen Thuy Vi, B.B.A. \\ International University (VNU HCMC) \\ Thu Duc District, HCMC VIETNAM \\ Tran Thi Tuong Vi, M.B.A. \\ International University (VNU HCMC) \\ Thu Duc District, HCMC VIETNAM \\ Ho Nhut Quang, Ph.D. \\ International University (VNU HCMC) \\ Thu Duc District, HCMC VIETNAM
}

\begin{abstract}
Training and development is a fundamental element to meet the goals, strategies of the organization. The quality of human resources does not currently meet the demands of the enterprises. One of the biggest drawbacks in employees is the lack of their own thinking ability, creativity, and initiative in their work. The research focuses on the question of how Training and Development impact on Employee Loyalty and what the factors affecting employee loyalty are. The purpose of this research is to identify and evaluate the impact of Training and Development on Employee Loyalty - The case of Beton 6 Corporation, which examine how Training and Development affect Employee Loyalty through Technique Skills, Functional Skills, Supervisor Support, and Employee Performance. The research uses descriptive statistics and quantitative method (the survey was taken in 2017 via questionnaires with sample size $n=512$ employees aging from 25 to more than 45 with many types of work). The conceptual model is based on the model by Muhammad \& Aiman (2015) to measure the impact of Training and Development on Employee Loyalty. After analyzing the data using SPSS and AMOS software, the research results show that Training and Development indirectly affect Employee Loyalty and the factor Employee Performance has the highest level_of direct influence on Employee Loyalty. Although there are some limitations to this study, such as samples, questionnaires and data collection, this research hopes to contribute meaning to future research on employee loyalty in the field of construction and concrete production.
\end{abstract}

Keywords: Construction industry, concrete production, Beton 6 Corporation, Training and Development, Technique Skills, Functional Skills, Supervisor Support, Employee Performance, Employee Loyalty.

\section{INTRODUCTION}

Training and Development bring many benefits to organizations. Moreover, it also contributes to satisfying the demands of workers, such as: creating a good relationship between workers and business; creating a professional style for employees; adapting employees for future work; meeting the need learning and personal development of employees; enforcing the company vision for employees; promoting employee loyalty. Beton 6 Corporation was chosen for this research. Beton 6 Corporation is one of the six members of the HB Group. This Corporation is one of the leading companies in Vietnam specializing in manufacturing precast concrete elements, constructing of infrastructure. With nearly 800 employees are working in the company and with the amount to pay for the training and development programs up to 
354,300,000 VND in last year, Beton 6 always want each employee can have the opportunity to develop as well as contribute to the development of the company. The main objective of this research is to analyze the impact of Training and Development on employee loyalty in the company as well as identify the factor affects to employee loyalty, evaluate the degree of importance of each factor, suggest recommendation, solve the problem and improve the situation. The results of the research can help organizations improve their Training and Development programs based on the factors that influence employee loyalty the most.

\section{THEORETICAL BACKGROUND AND HYPOTHESES}

Training: a procedural method to study and development to improve individual, team, and organizational effectiveness (Goldstein IL; Ford JK, 2002).

Development: an activity to acquire the new knowledge or skills for purposes of personal growth (Goldstein IL; Ford JK, 2002).

Employee Loyalty: the belief that being an employee of the organization is in their best interests (Susan E. Wyse, 2012).

Technical Skill: the knowledge and capabilities to perform specialized tasks related to a specific field (Doyle, 2016).

Functional Skills: Skills that are not learned in school, such as social skills, communication, leadership, teamwork, time management skills, etc. (Kautz, T. D., Heckman, J., Diris, R., ter Weel, B., \& Borghans, L., 2014).

Supervisor Support: the extent to which leaders value their employees' contributions and care about their well-being (Powell, 2011).

Employee Performance: The achievement of specific tasks measured against predetermined or identified standards of accuracy, completeness, cost, and speed (Sultana, Irum, Ahmed, \& Mahmood, 2012).

Conceptual Model: the proposed model gives the explanation about the relationship between Training \& Development and Employee Loyalty. Employee loyalty is the dependent variable while employee performance, Technical skills, functional skills and supervisor support and Training \& Development are the independent variables (Muhammad \& Aiman, 2015). The model is shown in the Appendix (Figure 1).

\section{Hypotheses}

In order to achieve the research aim, hypotheses are created to be tested. There are hypotheses of the thesis as below:

H1: Training \& Development will positively affect Technical Skills.

H2: Training \& Development will positively affect Functional Skills.

H3: Training \& Development will positively affect Supervisor Support.

H4: Technical Skills will positively affect Employee Performance.

H5: Functional Skills will positively affect Employee Performance.

H6: Supervisor Support will positively affect Employee Performance.

H7: Employee Performance will positively affect Employee Loyalty. 


\section{Construct conceptual model}

\section{METHODOLOGY}

Secondary data is collected properly and promptly. Besides, several previous studies can be reviewed and analyzed to get the main results of those research. Combining all the information of secondary data, findings and gaps of the previous papers, the conceptual model of this study is created accordingly.

\section{Survey design and analysis}

This survey focusses on the income, professional, age, job level of respondents. The sample size is around 500, which is reasonable to analyze and generalize for employees in the company.

AMOS and SPSS are used to analyze data from the survey. They generate the results of the sample after inputting data to AMOS/SPSS with CFA/SEM. Then, the reliability and validity tests are conducted. For reliability test, either the Cronbach's alpha (SPSS) or CR coefficient (AMOS) can be used, while EFA (SPSS) or CFA (AMOS) are be used to test the validity of sample results.

\section{Measurement Scale}

This research uses the Five-point Likert Scale to measure the 32 statements that represent the influence on Employee Loyalty on a scale from 1 to 5, which 1 is Totally Disagree, 2 is Disagree, 3 is Neutral, 4 is Agree, and finally, 5 is Totally Agree.

\section{Demographic}

\section{RESULTS}

The proportion of male employee (58.8\%) is higher than the proportion of female employee (41.2\%) in 500 samples (Figure 2, Appendix)

\section{Age}

People under 25 years old accounted for $48.2 \%$ of the sample, followed by people from 30 to 45 with $32.6 \%$. The percentage is $16.6 \%$ for people between 25 and 30 and people over 45 years old has the lowest percentage, 2.5\%. (Figure 3, Appendix)

\section{Income}

Employees earning 7 to 15 million VND per month accounts for half of the sample size, while people earning 5 to 7 million VND/month makes up 30.3\%. 15\% of the sample size earn over 15 million VND/month and only 4.7\% makes less than 5 million. (Figure 4, Appendix)

\section{Experience}

People with "More than 2 years" and "from 0 to 6 months" experience account for $45.7 \%$ and $25.2 \%$ respectively. The percentage of respondents who get experience from 1 to 2 years is $22.3 \%$. Meanwhile, only $6.8 \%$ of the respondents have from 6 months to 1-year working experience (Figure 5, Appendix)

\section{Major}

The highest result in this section is "Production" with 28.1\%. Followed by "Finance" with 15\% of the sample size. Next is a group of "Supply" with $14.3 \%$ and a group of "Sale" with 12.7\%. The rest is a group of "Human Resource Management" with 12.5\%, "IT" with 10.9\%, Construction with 2.1\% and "Residential Work" with 4.3\% (Figure 6, Appendix) 


\section{Key factors that impact on employee's loyalty by residents' decision}

Eight factors are presented to be chosen and we have recorded how many people said Yes to each factor: Communicate with many people and expand the relationships; Bonus and incentives are satisfied; Famous corporate brand name; Company strategy is clear and reliable; Good leadership; Satisfactory income; Good co-worker relationships; Good working condition and safe working environment.

The factor selected the most is "Satisfactory income" with 69.9\%. Followed by, the "Good Leadership" with $47.7 \%$ in the second place. Finally, "Good working condition and safe working environment" with $41 \%$ is the final factor that was chosen by residents that can have a significant impact on their loyalty. (Figure 7, Appendix)

\section{Technical Skills}

5 options on the scale of 1 to 5 were used to measure "Technical Skills": I am confident about all aspects of specialist knowledge; I can access a lot of new knowledge to apply in my current job; I know and understand very well the specialist knowledge I need in my job; Specialist knowledge helps me to show the professional in my work; Now, Specialist knowledge is enough for me at work. The results showed that all aspects were high, ranging from 3.6 to 4.08 with an average of 3.94104. This shows that the company's employees can fully understand the knowledge to adapt to their work well, and they realize that they can acquire some new knowledge to support their work. (Table 1, Appendix)

\section{Functional Skills}

5 items were used to measure "Functional Skills": Colleagues are always ready to listen to my ideas; I always control the pressure and emotions in my work; I understand my role, duties, and responsibilities in my team; I understand and know how to work with my team; I know how to manage the time for my work. The answers range from 3.7 to 3.8 with an average of 3.80194. This shows that the company's employees have enough soft skills to get the job done in the best way. In addition, they can work well together to achieve the best results (Table 2, Appendix)

\section{Supervisor Support}

7 items were used to measure "Supervisor Support": Supervisor encourages me to attend training program organized by the company; Supervisor cares about my needs to have knowledge and skills; Supervisor helps me to understand how I am doing; Supervisor helps me to improve myself; Supervisor takes prompt and fair corrective action on employees who fail to perform their work satisfactorily; Supervisor gives me clear instructions; Supervisor is available when I need advice. The result shows that supervisor's actions and images of the company staff are very good. All employees receive the help of supervisors when they need it. The statement "Supervisor takes prompt and fair corrective actions on employees who do not perform their work satisfactorily" has the highest average. (Table 3, Appendix)

\section{Training and Development}

5 items were used to measure "Training and Development": The company's training and development programs have provided more specialist knowledge in the work process; Participating in training courses has given me more chances to understand my roles and responsibilities in job; The company regularly organizes training courses which are suitable for my current job; The company's training and development program has improved my skills and work experience; When I joined the Training and Development Program, I learned how to develop teamwork skills to get better results at work. The result shows that the training programs have a positive influence on employees in the company. The program provides the 
new knowledge and skills for every employee and helps them understand more about their responsibility. (Table 4, Appendix)

\section{Employee's Performance}

5 items were used to measure "Employee's Performance": I can use the expert knowledge in my current job; I can solve easily every problem in my task; I can use and utilize soft skills in my job; I can communicate and promote myself at work with my colleagues and clients; The supervisor provides many positive comments to each team member. This shows employees can leverage their technical knowledge as well as soft skills to complete their work. In addition, they can also promote themselves with colleagues and customers. (Table 5, Appendix)

\section{Employee Loyalty}

5 items were used to measure "Employee Loyalty": I want to stay long with the company; Even if another company pay me with higher salary, I still choose to stay with the company; If I have been invited by another company, have good working conditions and are comparable to the current company, I still choose to stay with the current company; I always advise colleagues to work in a long-term with the company; I always consider myself is an indispensable member of the company. The result shows the loyalty of employees to the company is quite positive. However, the statement "If I have been invited by another company, have good working conditions and are comparable to the current company, I still choose to stay with the current company" has the lowest mean out of 5. This shows that if an employee is invited by another company with better job conditions, the loyalty of the employee at the current company decline and fluctuate in a negative direction. (Table 6, Appendix)

\section{Descriptive Analysis}

Many statistical tests were used to verify the data. First of all, we used Cronbach's Alpha to check the reliability of the data following the principle of (George \& Mallery, 2003). After we have run the tests for all data, we concluded that all data passed the reliability test and none was eliminated. Next, we used Exploratory Factor Analysis to summarize the data, which shows the relationship between the groups of observed variables with hidden variables called factors. The combination of exploratory factor analysis and assertive factor analysis creates a set of factors that ensure high reliability and efficiency of data. In addition, EFA makes the factor more meaningful but still contains the full content of the original factor. (JR, C.Black, J.Babin, \& E.Anderson, 1998). Correlation test using SPSS shows that all 5 factors have a strong and positive relationship with Loyalty. Next, we used Confirmatory Factor Analysis to measure how well the collected variables can fit a model.

After data were verified, Hypotheses Testing were conducted. The results of the Hypotheses Test (Table 7, Appendix) show that all independent variables: "Technical Skills, Functional Skills, Supervisor Support, Training and Development, Employee Performance" contributed significantly and impacted positively to the dependent variable "Employee" Loyalty. Moreover, this result also shows that "Technical Skills, Functional Skills, Supervisor Support" have a significant correlation with Employee Performance.

\section{IMPLICATIONS FOR TRAINING AND DEVELOPMENT}

After many tests, the results also show that Training and Development not only contributes to the employees in terms of skills, knowledge and the closeness of the relationship between Supervisors and employees but also contributed to Employee Loyalty through Employee Performance. Therefore, besides some professional skill training programs, the company 
should also have some exchanges and extra activities that can increase employee performance, as well as create the trustworthy and outstanding company in the minds of employees.

The evidence in the study shows that the relationship between Technique Skills and Employee Performance is very high. Thus, it is necessary to focus on Technical Skills so that employees feel more confident in their work, and their performance is better. When employees have enough skills to solve every problem in a flexible way, their confidence will be increased, and their productivity will be also increased. This will contribute to the desire to stay with the company. When Training and Development program creates more opportunities for employees and supervisors to interact with each other, their relationship will develop in a positive way and thus improve Employee Performance leading to higher Employee Loyalty.

The influence of Employee Performance on Employee Loyalty is the highest. If employees constantly achieve high performance, the name of the company will always be on the top of the list of companies that are worth working for a long period.

Next, although Training and Development do not impact Employee Loyalty directly, they have a positive effect on Technique Skills, Functional Skills, and Supervisor Support, and all three factors give employees the confidence in their knowledge, skills, and relationships which also have a positive effect on Employee Performance. When Employee Performance is satisfied, it had the greatest impact on Employee Loyalty. Overall, Training and Development is an important part when the company wants to improve employee loyalty.

\section{LIMITATION}

Due to the limitation of capacity and cost, research is conducted only among employees within a company for a short period of time; however, in the future, other research can be studied for a long time with a wider scope to increase accuracy. The results can help companies increase quality and performance of employees.

\section{CONCLUSION}

The purpose of this research is to find out which factors of Training and Development contribute to Employee Loyalty in a company. Beton 6 was chosen as the research company. The results suggest that Technical Skills, Functional Skills, and Supervisor support influence Employee Performance positively. This, in turn, will enhance Employee Loyalty to the company. It is recommended that organizations construct their Training and Development programs according to these factors in order to retain great employees.

\section{Reference}

Goldstein IL; Ford JK. (2002). Training in Organizations 4th edition. Belmont: CA:Wadsworth. Imran, M., \& Tanveer, A. (2015). IMPACT OF TRAINING \& DEVELOPMENT ON

Jabnoun \& Al-Tamimi. (2003). Measuring perceived service quality at UAE commercial banks. Jabnoun \& AlTamimi.

JR, J. F., C.Black, W., J.Babin, B., \& E.Anderson, R. (1998). Multivariate Data Analysis (5th Edition). Upper Saddle River, NJ: Prentice Hall.

Kautz, T. D., Heckman, J., Diris, R., ter Weel, B., \& Borghans, L. (2014). Fostering and Measuring Skills: Improving Cognitive and Non-Cognitive Skills to Promote Lifetime Success. Cambridge: MA: National Bureau of Economic Research.

Powell, D. J. (2011, April 8). Supervisor Support. Retrieved from Scontrino-Powell: http://www.scontrinopowell.com/2011/supervisor-support-a-key-ingredientineffective-leadership/

Sultana, A., Irum, S., Ahmed, k., \& Mahmood, N. (2012). Impact of Training on Employee Performance. A Study of 


\section{Telecommunication Sector in Pakistan, 646-661.}

Susan E. Wyse. (2012, June 15). Improve Employee Loyalty. Retrieved from Snap Surveys: https://www.snapsurveys.com/blog/tips-improve-employee-loyalty-part-1/

\section{APPENDIX}

\section{Figure 1: Conceptual Model}

H1

H2

H3

H6

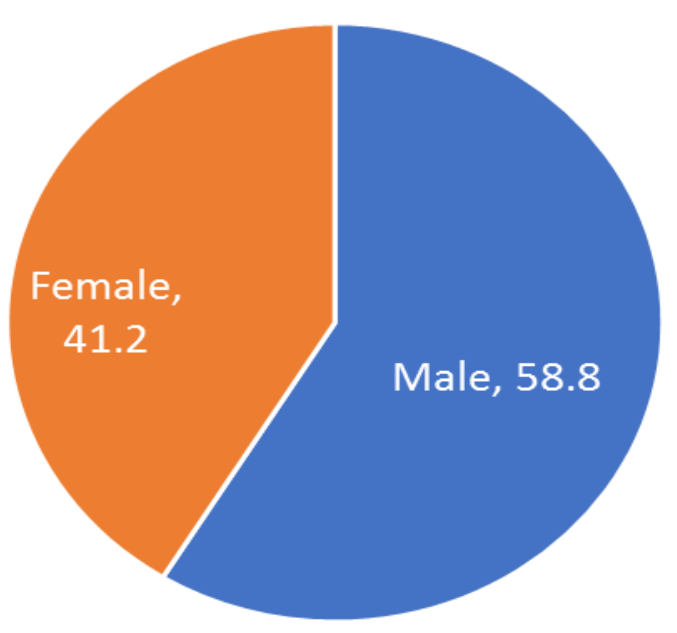

Figure 2: Respondent's Gender 


\section{AGE}

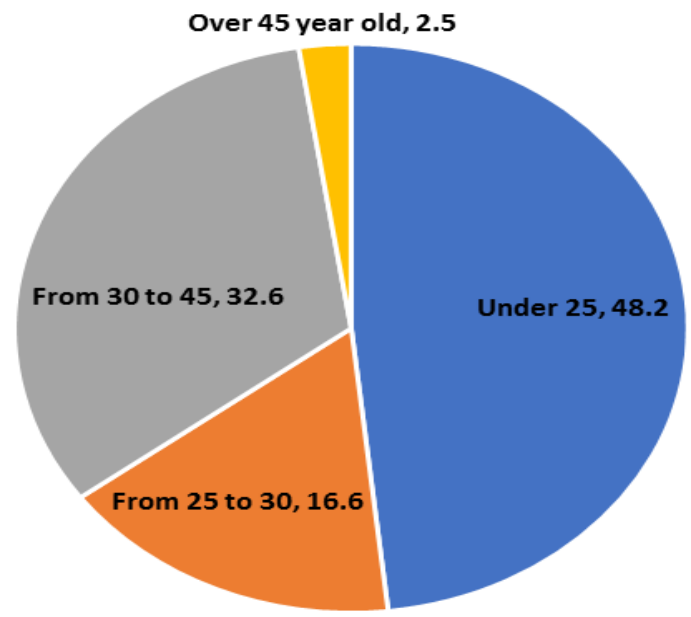

Figure 3: Respondent's Age

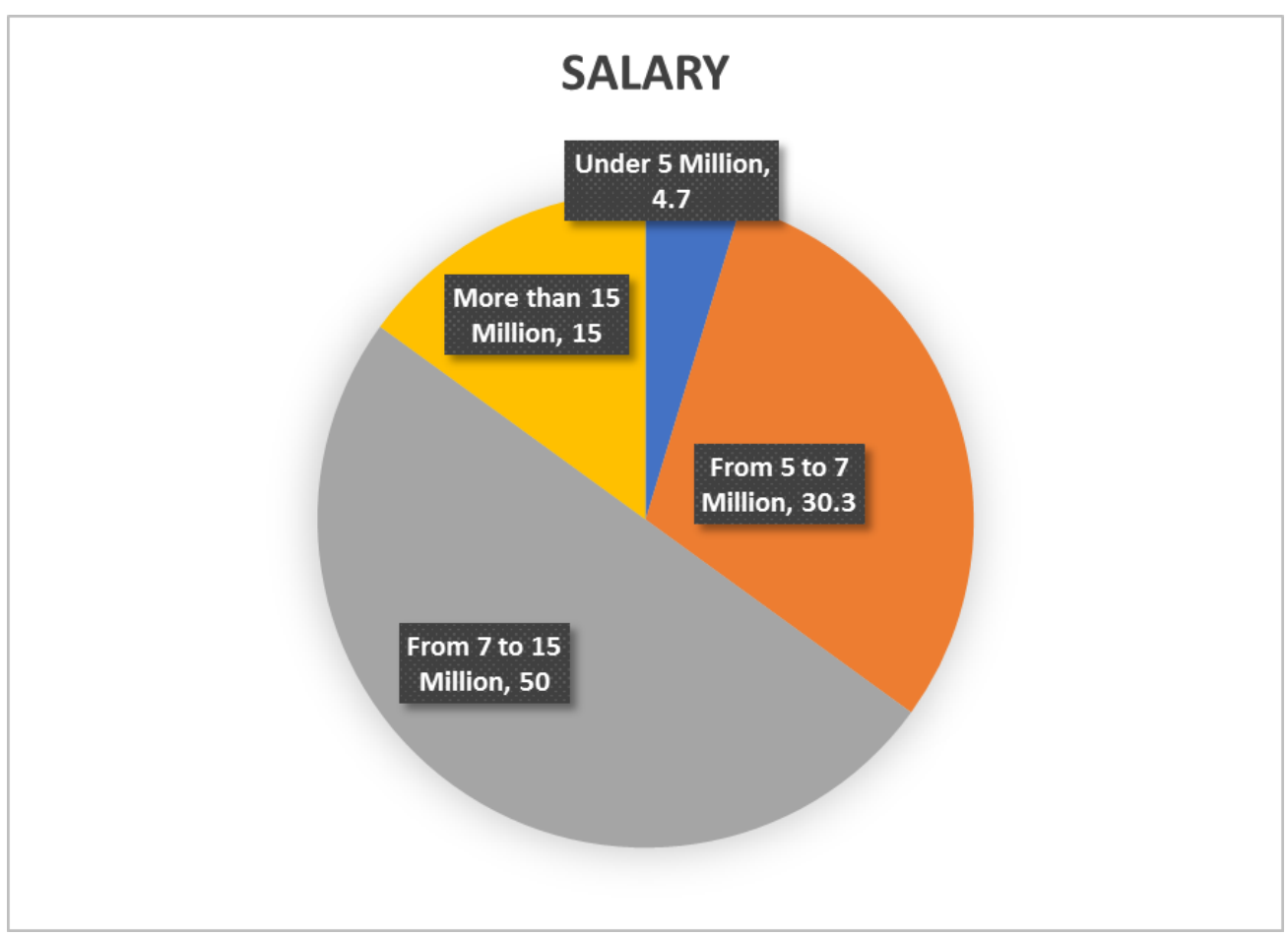

Figure 4: Respondent's Salary 


\section{Experience}

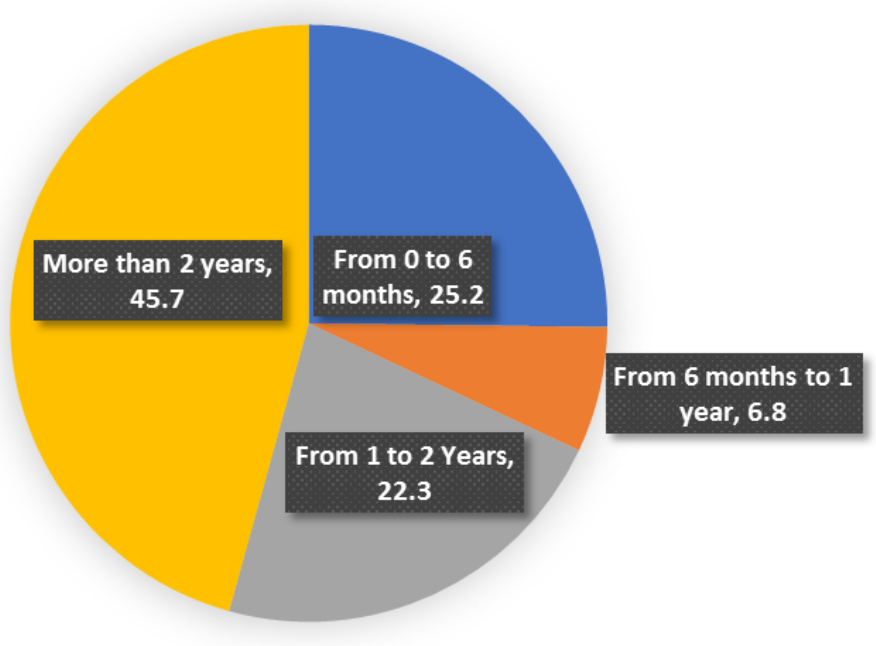

Figure 5: Respondent's Experience

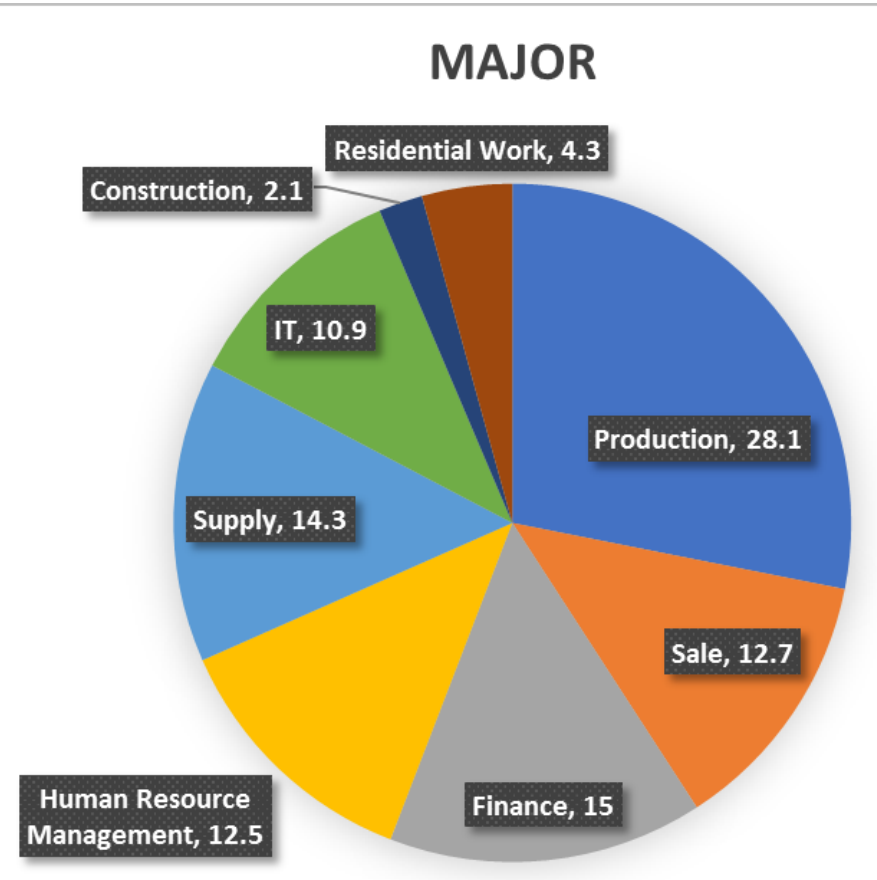

Figure 6: Respondent's Major 


\section{Key factors that impact on employee's loyalty}

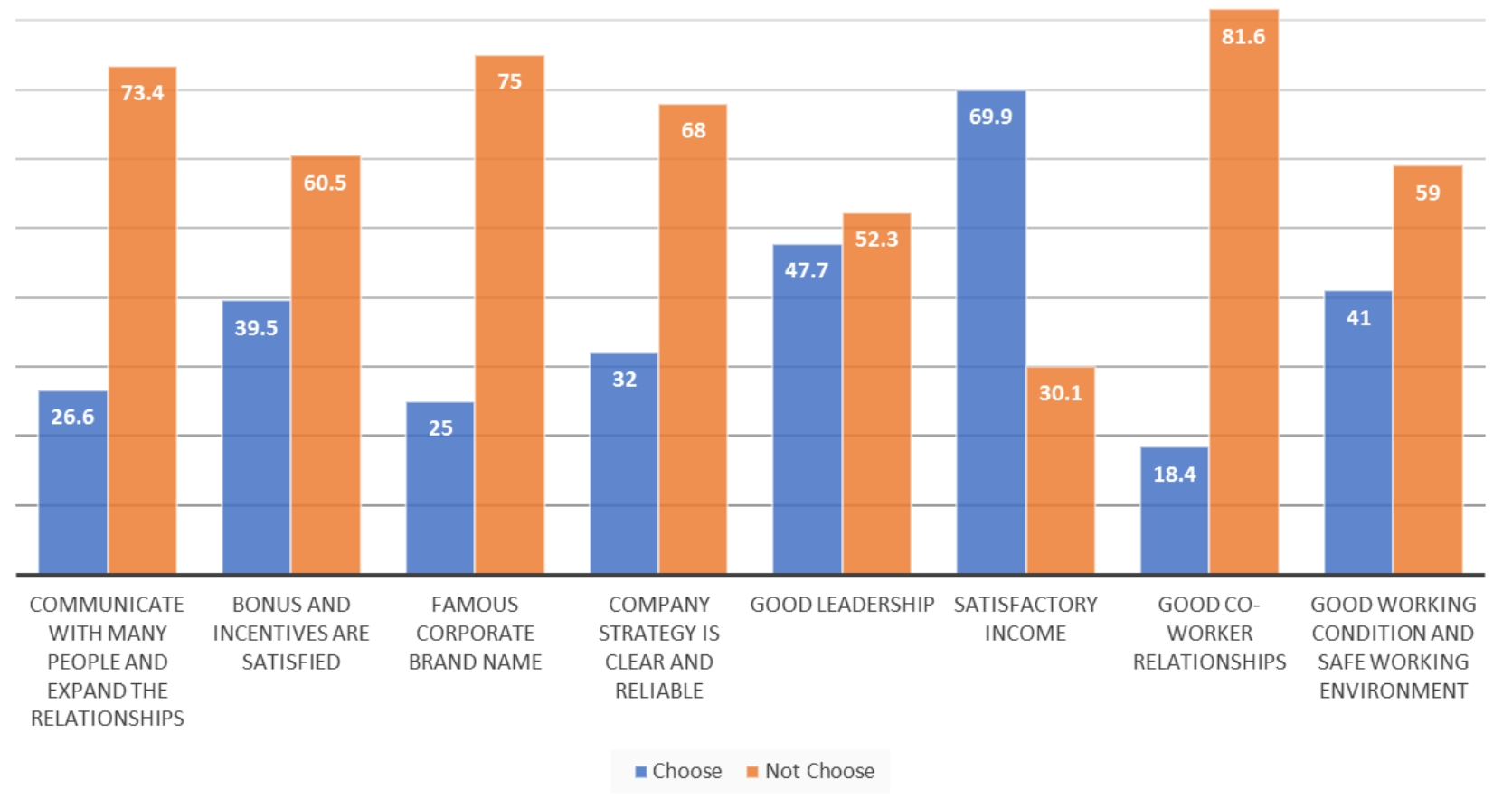

Figure 7: Key Factors by residents' decision

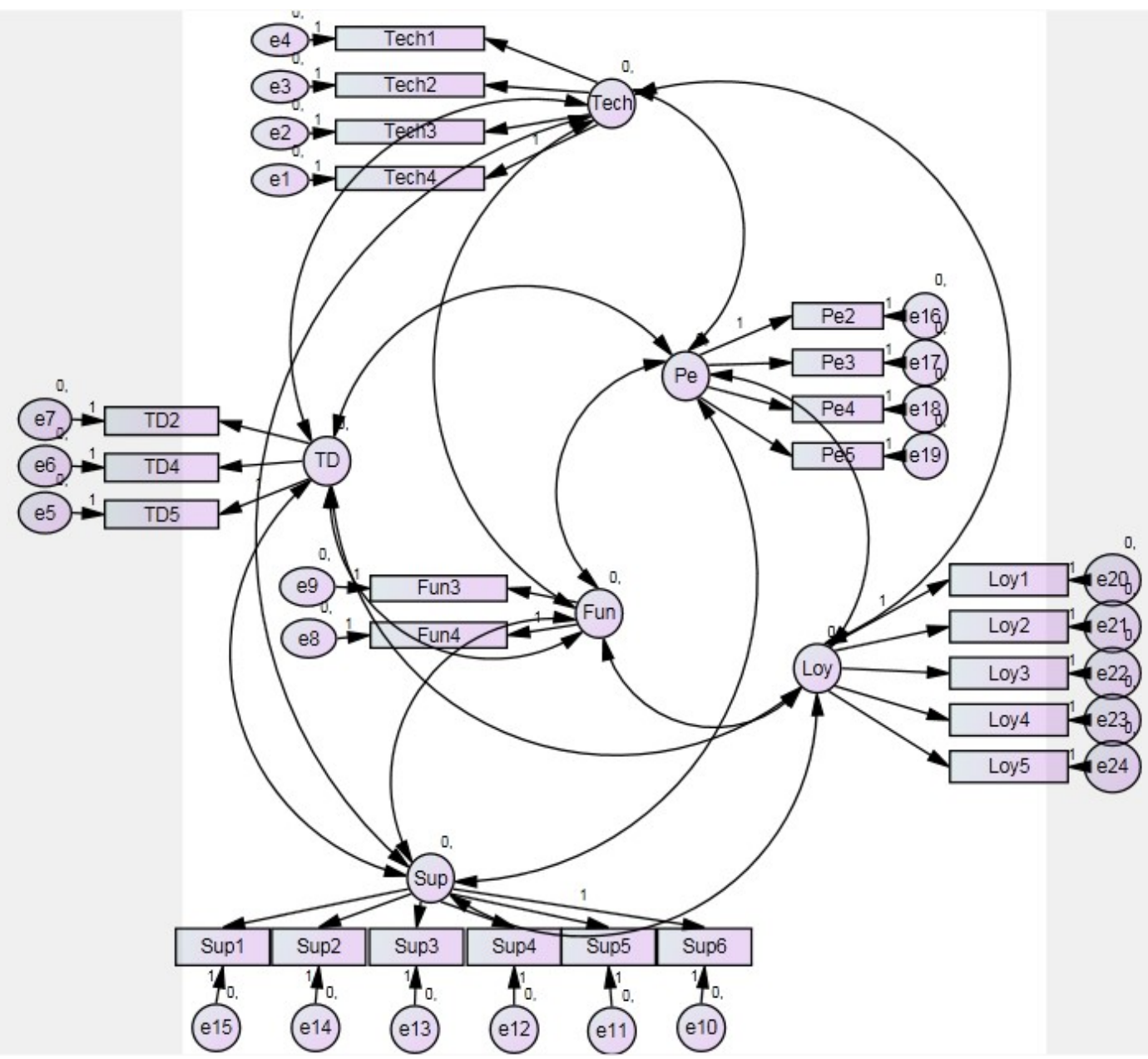

Figure 7: CFA Model 
Table 1: Descriptive Statistics of "Technique Skills"

\begin{tabular}{|c|c|c|c|c|c|}
\hline & $\mathbf{N}$ & Minimum & Maximum & Mean & Std. Deviation \\
\hline Tech1 & 512 & 1.00 & 5.00 & 4.0020 & .91839 \\
\hline Tech2 & 512 & 1.00 & 5.00 & 4.0840 & .80530 \\
\hline Tech3 & 512 & 1.00 & 5.00 & 3.9551 & .82156 \\
\hline Tech4 & 512 & 1.00 & 5.00 & 4.0137 & \\
\hline Tech5 & 512 & 1.00 & 5.00 & 3.6504 & .98563 \\
\hline Valid N (listwise) & 512 & & & & \\
\hline
\end{tabular}

Table 2: Descriptive Statistics of "Functional Skills"

\begin{tabular}{|c|c|c|c|c|c|}
\hline & $\mathbf{N}$ & Minimum & Maximum & Mean & Std. Deviation \\
\hline Fun1 & 512 & 1.00 & 5.00 & 3.8105 & .79704 \\
\hline Fun2 & 512 & 1.00 & 5.00 & 3.7539 & .84515 \\
\hline Fun3 & 512 & 1.00 & 5.00 & 3.8887 & .77213 \\
\hline Fun4 & 512 & 1.00 & 5.00 & 3.7949 & .78820 \\
\hline $\begin{array}{l}\text { Fun5 } \\
\text { Galid }\end{array}$ & 512 & 1.00 & 5.00 & & \\
\hline Valid $\mathbf{N}$ (listwise) & 512 & & & & \\
\hline
\end{tabular}

Table 3: Descriptive Statistics of "Supervisor Support"

\begin{tabular}{|c|c|c|c|c|c|}
\hline & & & & & \\
& $\mathrm{N}$ & Minimum & Maximum & Mean & Std. Deviation \\
\hline Sup1 & 512 & 1.00 & 5.00 & 3.6523 & .90672 \\
Sup2 & 512 & 1.00 & 5.00 & 3.3789 & .92211 \\
Sup4 & 512 & 1.00 & 5.00 & 3.5566 & .93879 \\
Sup5 & 512 & 1.00 & 5.00 & 3.6172 & .97017 \\
Sup6 & 512 & 1.00 & 5.00 & 3.6582 & .92072 \\
Sup7 & 512 & 1.00 & 5.00 & 3.5801 & .89870 \\
Valid N (listwise) & 512 & 1.00 & 5.00 & 3.5918 & .92971 \\
& 512 & & & & \\
\hline
\end{tabular}


Table 4: Descriptive Statistics of "Training and Development"

\begin{tabular}{|c|c|c|c|c|c|}
\hline & $\mathbf{N}$ & \multirow{4}{*}{$\begin{array}{c}\text { Minimum } \\
1.00 \\
1.001 .00 \\
1.001 .00\end{array}$} & Maximum & \multirow{5}{*}{$\begin{array}{c}\text { Mean } \\
3.7383 \\
3.7305 \\
3.3828 \\
3.4023 \\
3.4590\end{array}$} & \multirow{2}{*}{$\begin{array}{c}\text { Std. Deviation } \\
.78255\end{array}$} \\
\hline TD1 & 512 & & 5.00 & & \\
\hline TD2 & 512 & & 5.00 & & .84724 \\
\hline TD3 & 512 & & 5.005 .00 & & 1.03837 \\
\hline TD4 & 512 & & & & .91425 \\
\hline TD5 & 512 & & 5.00 & & .92067 \\
\hline Valid N (listwise) & & & & & \\
\hline & 512 & & & & \\
\hline
\end{tabular}

Table 5: Descriptive Statistics of "Employee's Performance"

\begin{tabular}{|c|c|c|c|c|c|}
\hline & & & & & \\
& N & Minimum & Maximum & Mean & Std. Deviation \\
Pe1 & 512 & 1.00 & 5.00 & 3.6465 & .88366 \\
Pe2 & 512 & 1.00 & 5.00 & 3.7617 & .83576 \\
Pe3 & 512 & 1.00 & 5.00 & 3.8848 & .77662 \\
Pe5 & & 1.00 & 5.00 & 3.8418 & \\
Valid N (listwise) & 512 & 1.00 & 5.00 & 3.6797 & .8223 \\
& 512 & & & & \\
\hline
\end{tabular}


Table 6: Hypotheses Testing

\begin{tabular}{|l|c|c|c|}
\hline \multicolumn{1}{|c|}{ HYPOTHESIS } & $\begin{array}{c}\text { STANDARDIZED } \\
\text { REGRESSION } \\
\text { WEIGHT }\end{array}$ & $\begin{array}{c}\text { P-VALUE } \\
\text { (P-VALUE } \leq \text { 0.05) }\end{array}$ & RESULT \\
\hline $\begin{array}{l}\text { H1: Training \& Development will } \\
\text { positively affect Technical Skills }\end{array}$ & 0.397 & 0.000 & Supported \\
\hline $\begin{array}{l}\text { H2: Training \& Development will } \\
\text { positively affect Functional Skills }\end{array}$ & 0.361 & 0.000 & Supported \\
\hline $\begin{array}{l}\text { H3: Training \& Development will } \\
\text { positively affect Supervisor Support }\end{array}$ & 0.319 & 0.000 & Supported \\
\hline $\begin{array}{l}\text { H4: Technical Skills will positively affect } \\
\text { Employee Performance }\end{array}$ & 0.462 & 0.000 & Supported \\
\hline $\begin{array}{l}\text { H6: Supervisor Support positively affects } \\
\text { Employee Performance }\end{array}$ & 0.317 & & Supported \\
\hline $\begin{array}{l}\text { H5: Functional Skills positively affects } \\
\text { Employee Performance }\end{array}$ & 0.356 & 0.000 & \\
\hline
\end{tabular}

